\title{
ゼータ電位の理論と応用*
}

日本製紙株式会社 中央研究所 宮 西 孝 則

\section{Theory and Application of Zeta Potential in Papermaking}

\section{Takanori Miyanishi}

Central Research Laboratory,

Nippon Paper Industries, Co., Ltd.

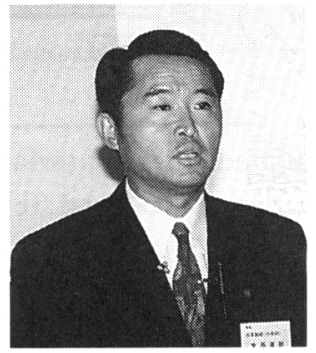

A laboratory system has been developed to measure simultaneously the zeta potential, flocculation, and drainage of pulp and filler suspensions under hydrodynamic shear flow. The magnitude and trend of on-line streaming potential measurements correlated well with off-line electrophoresis measurements. The slight deviation between two measurements showed the absorptivity difference of cationic chemicals with furnish components. The instrument was used to optimize flocculation and drainage for single retention systems and microparticle retention systems in a laboratory. Flocculation and drainage were affected by the order of chemicals, and the type of furnish. Drainage increases that occurred with the addition of bentonite were strongly influenced by charge neutralization.

\section{1.はじめに}

抄紙機のワイヤーパートでの紙層形成は，コロイド 化学と流体力学とのバランスにより決定される。抄紙 機の高速化, ッイン化, 紙の軽量化, 古紙の配合増な どに伴い機械設備だけでは解決できない問題も増えて いる。ウエットエンド研究の重要性が高まってきてい るが, ウエットエンドは白水循環系による時間遅れが あり大変複雑である。

図 1 に抄紙機のワイヤーパート回りのフローシート を示す。ミキシングチェストから抄紙機のリールまで をモデル化した。パルプは回収チェストからミキシン グチェストに移送され，ミキシングチェストで填料と ブロークが混合される。混合された原料はミキシング チェストからマシンチェストを経由し, 白水で希勫さ れて抄紙機のへッドボックスに送られる。ファースト

*第 4 回製紙技術セミナ一講演
パスリテンションは重要なパラメーターで, 塡料とパ ルプそれぞれ定義される。湿紙の一部はトリムされウ エットブロークとしてブロークチエストに回収される。 枠替每にリールの芯際の紙が少量残るので, これらは ドライブロークとしてパルパーに回収される。新原料

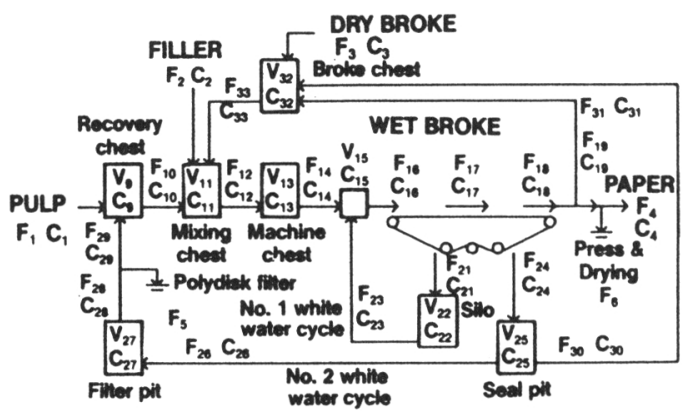

Fig.1 Flow diagram of the model. F $\times$ flow, $\mathrm{m}^{3} / \mathrm{min} ; \mathrm{V} \times$ volume, $\mathrm{m}^{3}, \mathrm{C} \times$ consistency (weight/volume), \% ${ }^{1)}$ 


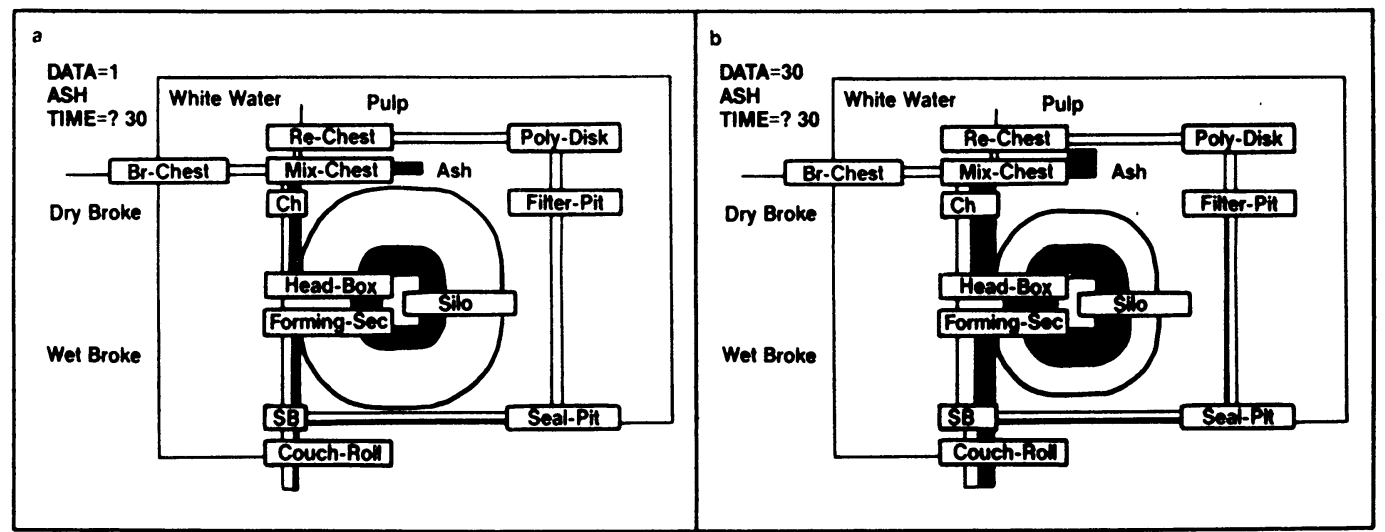

Fig.2 Simulated filler material balance after $30 \mathrm{~min}$ on a paper machine with (a) first-pass retention $\times 10 \%$ and (b) first-pass retention $\times 30 \%{ }^{1)}$

に切り替わるまでの中間製品もドライブロークになり， 抄紙機の運転状況によりドライブローク発生量は変化 する。静的シミュレーションで抄き替えの初期の物質 収支を計算し，それから動的シミュレーションで抄き 替えに伴う系内の物質置換の経時変化を計算した。動 的シミュレーションはシステムダイナミックスの原理 に基づいている。システムダイナミックスはストック とフローの 2 種類のパラメーターを用いてシステムの 動的解析を行うものであり，フィードバック系を持つ 社会科学の分野で数多くのシステムが開発されている。 塡料のファーストパスリテンションが $10 \%$ と $30 \%$ の 場合の, 30 分後の填料の物質収支を図 2-a と図 2-b に示した。フローシートの白抜きの部分は古い原料で, 黑い部分は新しい原料である。あるフローにおいて黑 い部分と旦い部分の幅の比率は, 新しい原料と古い原 料の比率を表わしている。ファーストパスリテンショ ンが $10 \%$ の場合は, 第一白水循環系を循環する量が 多く, 白水が新しい填料に切り替わる割合が小さく, 紙の切り替わりも遅くなっている。

このようにファーストパスリテンションが低いと， 白水を循環するファイン成分が多くなり, 抄き替え時 間, 濾水性, フェルト詰まり, スライム, ピッチなど の問題が発生しやすくなる。また微細䋐維は纎維間結 合を補強して, 紙の表面強度を保持するので，ファー ストパスリテンションが低下して紙に含まれる微細䋐 維量が減少すると紙粉トラブルが起こる。

低速長網抄紙機では，ファーストパスリテンション と地命いとは負の相関があり，ファーストパスリテン ションが晹くなると地合いが悪くなり，ファーストパ スリテンションが低くなると地合いが良くなる傾向を 小寸 (図3)。ファーストパスリテンションに強い影

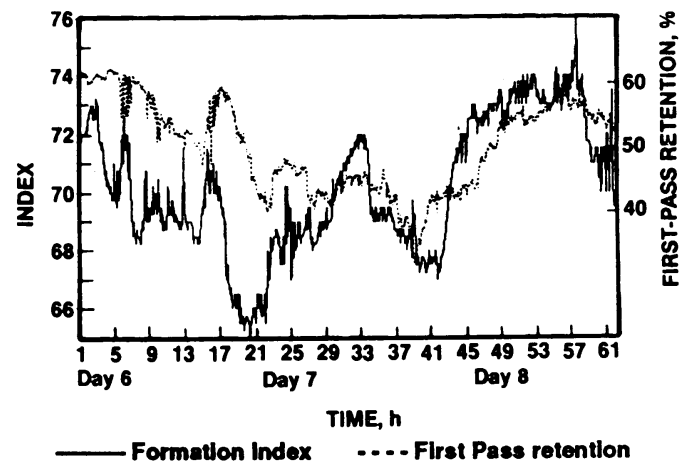

Fig. 3 Formation index and first-pass retention of a low-speed fourdrinier paper machine ${ }^{3)}$

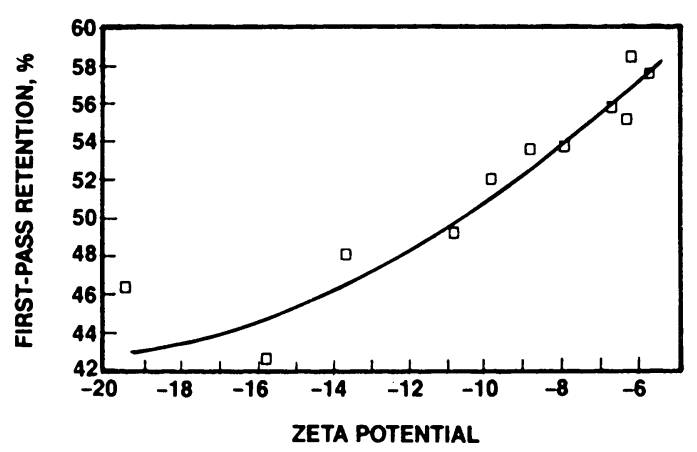

Fig.4 Zeta potential vs. first-pass retention of a low-speed fourdrinier paper machine ${ }^{3)}$

響を与えている操業因子はゼー夕電位であった(図 4)。 ゼー夕電位が等電点に近づくと,コロイド粒子間の電 気化学的反発力が減少して, 微細䋐維と長繊維, 填料 と長繊維との間にマイクロフロックが生成する。低速 
長網抄紙機のワイヤーパート上ではマイクロタービュ ランスが穏やかなので，マイクロフロックは容易に集 合してマクロフロックを形成する。マイクロフロック は地合いに悪影響を与えないが，マクロフロックは地 合いを悪化させる。

高速ギャップフォーマーは, ワイヤー上の強いマイ クロタービュランスにより, マイクロフロックが分散 した状態で紙層を形成するので地合は良いが, ファー ストパスリテンションは低い（図5）。図6にベルべ IIのフォーミングシューでの脱水モデルの概念を示す。 2 枚のワイヤーに挟まれた原料には, ワイヤー張力に よる内向きの力と遠心力による外向きの力が働いてい る。ワイヤーとパルプマットの濾過抵抗, 濾過圧力, 水の粘度などから計算したフォーミングシューの脱水 量プロファイルは，パイロット抄紙機の実測値と良く 一致した（図 7)。脱水初期にはワイヤー上にパルフ マットが十分形成されていないので脱水量が多く，フ アーストパスリテンションの低下要因になっているこ とがわかる。このように抄紙機械設備の進歩により,

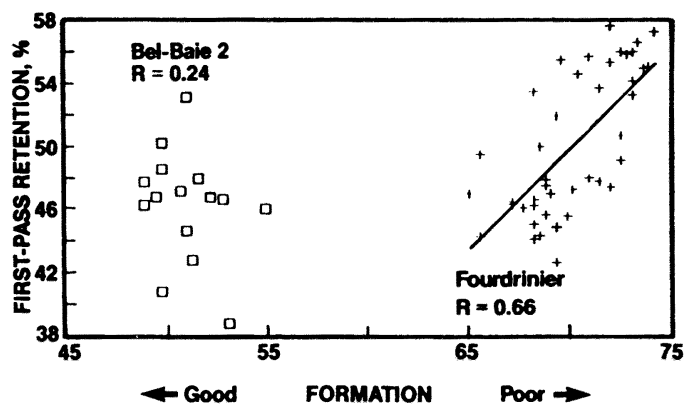

Fig. 5 Retention vs. formation ${ }^{3)}$

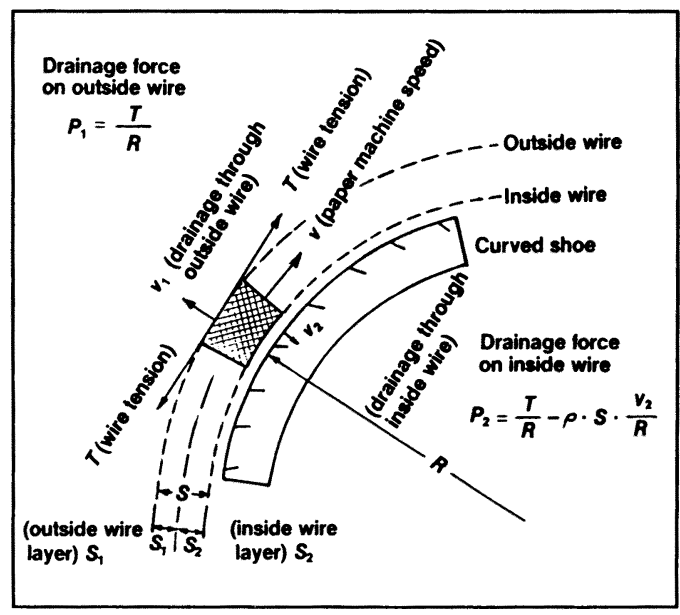

Fig.6 Drainage forces ${ }^{2)}$

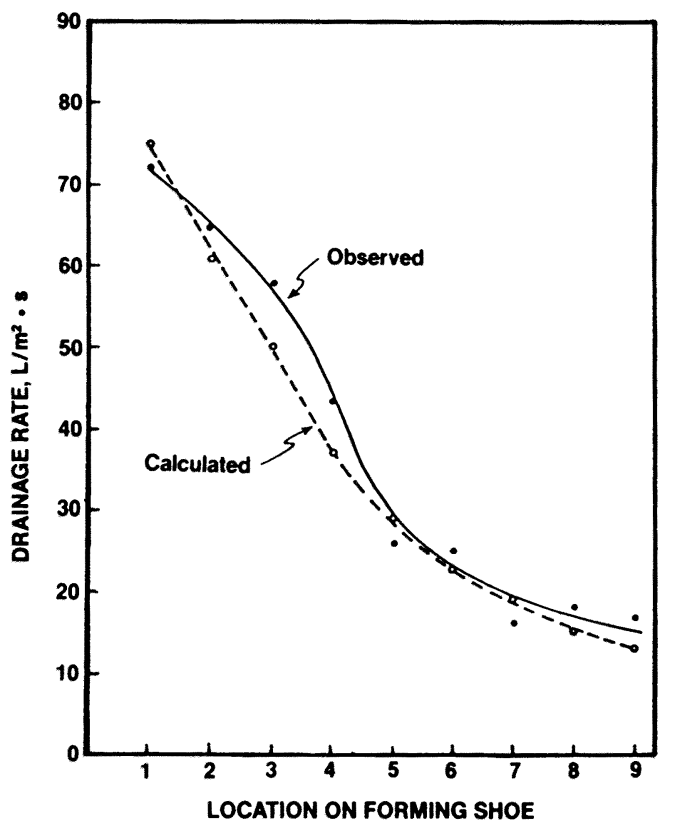

Fig.7 Observed and calculated drainage rate through inside wire ${ }^{2)}$

ファーストパスリテンションはますます低下する傾向 にある。

\section{2. 研究の目的}

ファーストパスリテンションをコロイド化学により 改善する方法として, 歩留まり剤がある。カチオン性 ポリマーを添加した後, アニオン性のマイクロパーテ イクルを添加するシステムは，高速抄紙でも地合を悪 化させることなく高歩留まりを達成できると言われて いる。しかし，アニオントラッシュの多い系では効果 が充分に発揮されないようである。薬品添加の指標と なる抄紙原料のコロイド表面電荷を迅速に正確に測定 する手段もない。そこで, ゼー夕電位, 濾水度, 凝集 度のオンライン测定装置を試作し，コロイド表面電荷 をコントロールして, リテンションと濾水効果を最大 に発揮する条件を探索したので紹介させて戴きたい。

\section{3. 理 論}

\section{1 ゼータ電位計}

製紙原料の主体であるパルプ繊維及び填料の表面は, 水中でマイナスに帯電している。これら固体表面の負 の電荷は, 反対の正の電荷を持つイオンを吸着し，い わゆる界面二重層を形成している。スターン層と拡散 層の境界面の電位と, そこから十分離れたパルプ影濁 液との電位の差をゼー夕電位と呼んでいる。同じ負の 
電荷を持つ粒子どうしは電気的に反発し，その絶対値 が大きいほど凝結しにくい分散系になり，反対に粒子 表面の電荷を中和すると粒子間の反発力が減少し凝集 系になる。詳しくは本セミナーの九州大学田中教授の 論文を参照して戴きたい。

電気泳動法は, 試料を一旦濾過して分別した微細成 分を測定セルに入れ，セルに電場を与えて荷電したコ ロイド粒子が移動する速度を計測する方法である。電 気泳動法は簡便で有効ではあるが，オフライン測定な のでサンプリングして測定するまでに時間と人手を要 し, 測定頻度が限られるため, 操業変化に対応できな いことがある。

オンライン測定装置は流動電位の原理に基づいてい る。最初にワイヤー上で試料のパルプマットを形成し, 次に圧力を加えてパルプマットを通じて白水を流し， パルプマットの両端に発生する流動電位を計測し， へ ルムホルッ，スモールコフスキーの計算式に代入して ゼー夕電位を求める。粘度, 誘電率は温度の関数とし て得られる。

$$
\begin{aligned}
& \xi=4 \pi \eta \lambda \mathbf{E} /(\varepsilon \mathbf{P}) \\
& \xi: \text { セ西電位, } \lambda: \text { 電導度, } \varepsilon: \text { 誘電率 } \\
& \eta: \text { 粘度, } \mathbf{E}: \text { 流動電位, } \mathbf{P}: \text { 圧力 }
\end{aligned}
$$

オンラインゼー夕電位計の事例が幾つか文献に発表 されているが, それらの測定值は電気泳動法の測定值 と著しく異なり, ゼー夕電位の変動は観測できるが, 測定值そのものの解釈は困難である。またパルプマッ ト形成のためのフィルターが目詰まりを起こしやすく， 保守に人手を要して, 長期連続使用ができない。そこ で, 目詰まりを防ぐために洗浄装置を工夫し, 濾液排 出バルブを取り付け, 電極のキャリブレーション方法 を考案し, 従来の欠陥を改良した装置を試作した（図 8)。

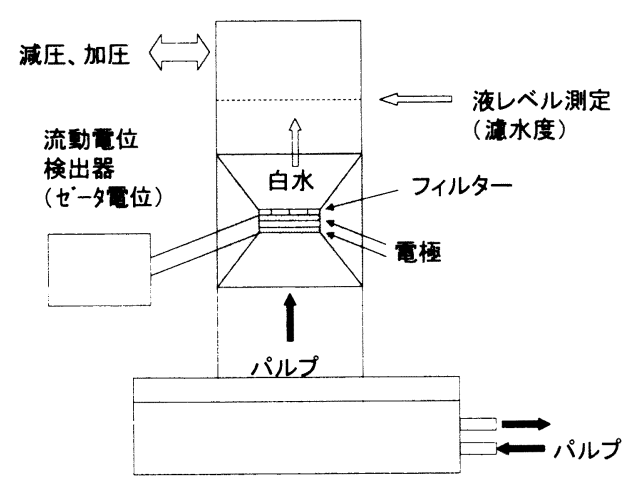

Fig.8 ゼー夕電位と滤水度測定装置

\section{2 濾 水 度計}

ゼー夕電位測定装置の上部セルの液レベルを $\mathrm{CCD}$ カメラで検出し, 単位時間内にフィルターマットを通 じて濾過された滤液量を計算し濾水度とした（図 8)。

\section{3 凝集度計}

糖, セルロース繊維などの結晶性物質は平面偏光を 透過させた際, 偏光面を変化させる性質を有し, これ らを光学活性物質と呼んでいる。この性質を利用して オンラインでの凝集測定を試みた。セルの污れ，光源 の劣化などを補正するために, 透過光の内, 偏光面の 変化した光（旋光：depolarized light）と変化しな かった光（透過光：reference light）の強度の比を計 算して出力値 (output) とした。

\section{出力値 $=$ 旋光強度 $* 10 /$ 透過光強度}

化学パルプは光学活性物質である結晶性のセルロー ス繊維を機械パルプよりも多く含んでいるので, 同一 濃度での出力值は, 化学パルプの方が機械パルプより も高くなった(図 9)。次に図 10 にLBKP に炭酸カル シウムを $20 \%$ 配合して $0.5 \%$ 濃度に調成したパルプ㦟 濁液にカチオン性 PAM を添加した時の凝集センサ 一出力值の変化を示した。旋光強度は変化しなかった が透過光強度は増加し, 結果としてそれらの比である

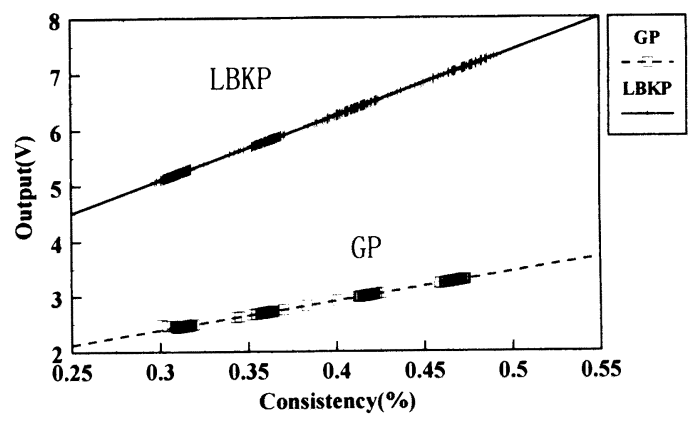

Fig.9 Sensor output vs. consistency

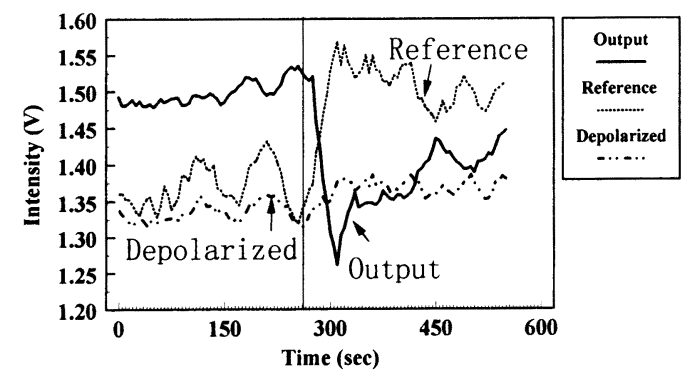

Fig.10 Effects of retention aid on flocculation

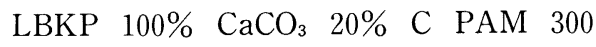
$\mathrm{ppm}^{6)}$ 


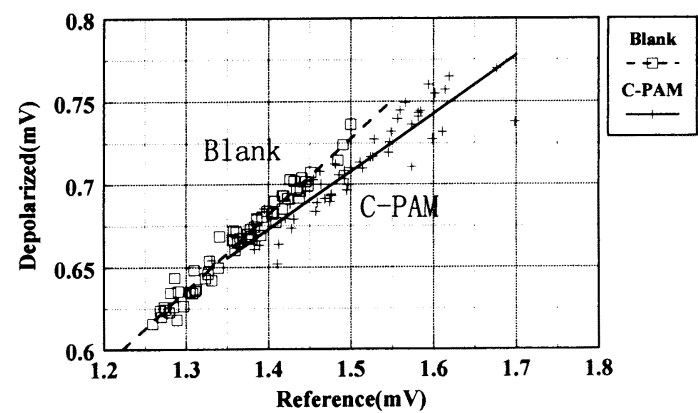

Fig.11 Depolarized light vs. reference light ${ }^{6)}$

出力値が減少した。図 11 に透過光強度と旋光強度の 関係を示した。旋光強度と透過光強度は直線関倸にあ るが，凝集によって透過光強度が上昇していることが わかる。その原理は, 水中に分散して光を散乱させて いた填料が繊維に歩留まって光の散乱が減少したこと と, フロックが生成して眯濁液にムラが発生し, 濃度 の薄い部分で光が透過しやすくなったことによると推 定される。この測定方法の利点はファインを分別する ことなく, 纎維, ファイン, 塡料, 溶解物を含む実機 の原料の凝集状態を, 剪断力を加えた状態で連続測定 できることである。

\section{4. 応用}

\section{1 電気泳動法と流動電位法の比較}

種箱に入る各パルプを所定の割合に配合して試料と した。試料に苛性ソーダを添加して $\mathrm{pH}$ を 6 にしてか ら，硫酸バンドを少しづつ添加して，ゼー夕電位の変 化を電気泳動法と流動電位法の 2 つの方法で測定した。 流動電位法はオンライン連続測定である。試料の一部 を10〜15 分毎にサンプリングして電気泳動法で測定 した(図 12)。硫酸バンドが無添加の状態では（時間 軸 $=0$ の時), 電気泳動法のゼー夕電位は流動電位法 のゼー夕電位よりも低かった。それは, 微細纎維は長 纎維よりも強くマイナスに荷電していることを示して

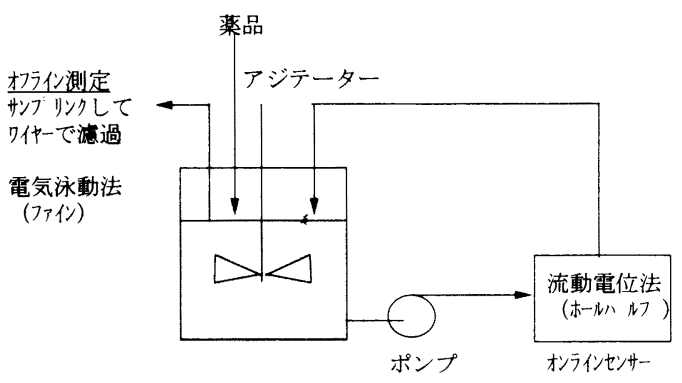

Fig.12 ゼー夕電位の比較実験装置
Zeta Potential (mV) Alum addition(\%)

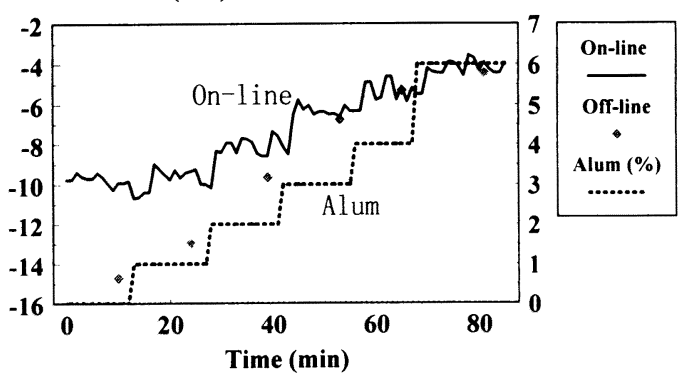

Fig.13 Effect of alum addition on charge of model newsprint furnish $(\mathrm{pH} 6)^{5)}$

いる(図 13)。硫酸バンドを添加していくと，両方の ゼー夕電位はマイナスからプラス方向に変化した。ゼ 一夕電位は，硫酸バンド添加率が $3 \%$ 以下では電気泳 動法の方が流動電位法よりも小さく，3\%以上添加す ると両方の測定值は一致した。

次に硫酸バンドの代わりにPEI (Poly-Ethylene Imine）を添加して同様の実験を行った(図 14)。PEI は強カチオンであり添加率は硫酸バンドの約 $1 / 10$ に した。ゼー夕電位は, 添加率が $0.3 \%$ 以下では電気泳 動法の方が流動電位法よりも小さく，0.3\%以上では 両方の測定值は一致した。同様にして, PAM (Poly Acryl Amide) の添加実験も行った。それから，実 機の抄紙機のへッドボックス原料を採取し，それに硫 酸バンド，PEI，PAMなどのカチオン性薬品を添加 する実験も行った。実機のへッドボックス原料には既 に硫酸バンドが添加されているので，カチオン性薬品 を添加する前のゼー夕電位は, 種箱パルプを配合して 調製した試料よりも高かった。

図 15 にこれらの全ての測定値を纏めてX軸に電気 泳動法のゼー夕電位（ファイン成分）を Y 軸に流動電 位法のゼー夕電位（ホールパルプ）をとってプロット した。電気泳動法と流動電位法のゼー夕電位はー10

Zeta Potential (mV) PEI addition(\%)

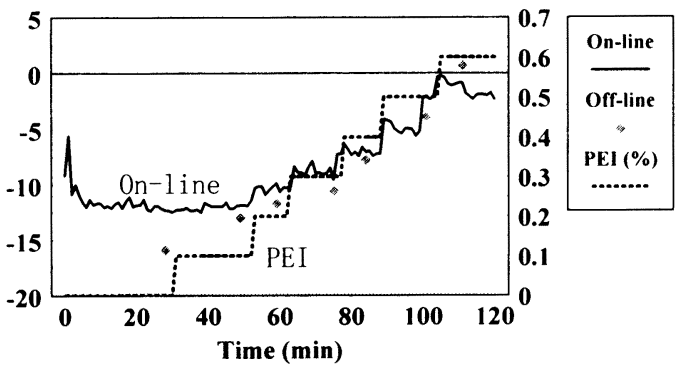

Fig.14 Effect of PEI addition on charge of model newsprint furnish $(\mathrm{pH} 6)^{5)}$ 


\section{Whole pulp ZP by streaming potential ( $\mathrm{mV}$ )}

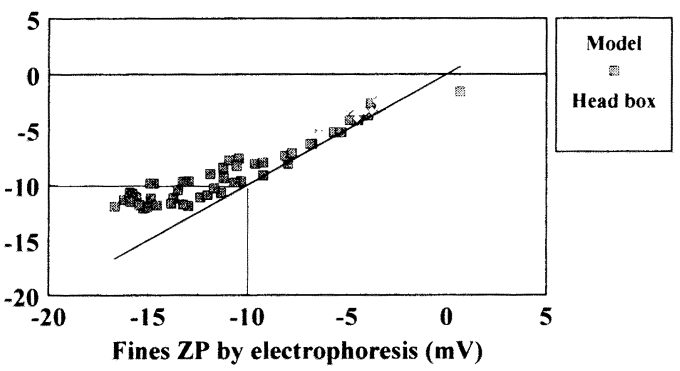

Fig.15 Zeta potential measured by streaming potential and electrophoresis instruments $^{5)}$

$\mathrm{mV}$ 以上:の領域では一致し, $-10 \mathrm{mV}$ 以下の領域では, 䉓気泳動法が流動電位法よりも小さく, 強いマイナス 電荷を示した。

カチオン性内添薬品は最初にアニオン性溶存物, 次 にファイン，そして最後に繊維に吸着する。従って最 初に添加した薬品は繊維よりも主としてファインに定 着するので，ファインだけを測定している電気泳動法 のゼー夕電位は大きく変化する。一方, 流動電位法で はホールパルプを測定し，ファイン，長繊維など全成 分の電荷の平均值がゼー夕電位として計算される。薬 品添加初期に於いては, 薬品はアニオン性溶存物とフ アインに主に定着し，まだ繊維にはそれ程多くは定着 していないので, ホールパルプのゼー夕電位は大きく 変化しない。薬品添加率を増やしていくと薬品は繊維 に吸着し始め, ファインと共に繊維の表面電荷も変化 するので，電気泳動法と流動電位法のゼー夕電位は一 致すると考えられる。図 15 のグラフの変曲点から, この原料系ではアニオン性溶存物とファインへのカチ オン性薬品の定着はゼー夕電位がー $10 \mathrm{mV}$ の点でほ ぼ光了していたと思われる。

カチオン要求量は紙料中の利用できる電荷サイト量 の测定であり，コロイド滴定により求如れる。電荷 の総量なので, 電荷の強さを表わすゼー夕電位とは異 なっている。ゼー夕電位は電荷の強さを与え，カチ才 ン要求量は粒子の負電荷を等電点まで中和するのに必 要な力チオン性薬品の量を表している。図16に, 硫 酸バンドを添加していった際のカチオン要求量と流動 電位法のゼー夕電位の変化を示した。硫酸バンドの添 加に伴ってゼー夕電位は上昇し，カチオン要求量は減 少した。ゼー夕電位がー $10 \mathrm{mV}$ 以上になるとカチオ ン要求量は平衡点に達した。これは，アニオン性溶存 物とファインへの硫酸バンドの定着が $-10 \mathrm{mV}$ 付近 で䒧了したことを示しており，四５で考察した電気泳

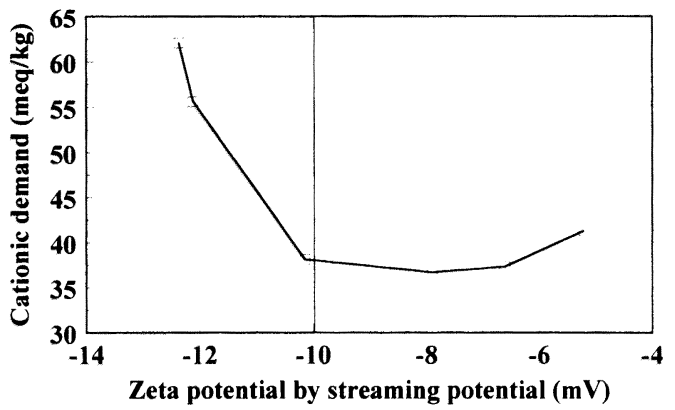

Fig.16 Effect of alum on cationic demand of newsprint model furnish $(\mathrm{pH} 6)^{5)}$

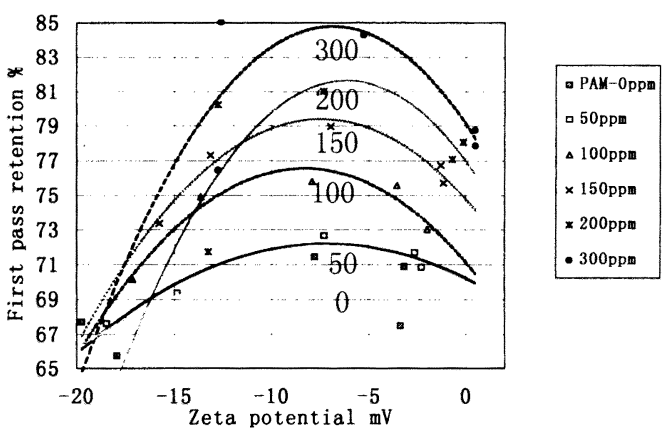

Fig.17 Zeta potential vs. First pass retention

動法と流動電位法の実験結果と一致した。

次にDDJ を用いてファインの歩留まりを测定した。 ゼー夕電位がー $10 \mathrm{mV}$ - $5 \mathrm{mV}$ の範囲でファインリ テンションは最大になった(図 17)。ゼー夕電位がー5 $\mathrm{mV}$ 以上になるとファインリテンションは低下した。 それは，コロイド表面電荷が完全に中和されると，力 チオン性 PAMの投錨点がなくなるためである。従 つて，機械パルプを配合した原料で高分子歩留まり剂 の効果を発揮させるためには, あらかじめゼー夕電位 を $-10 \mathrm{mV} \sim-5 \mathrm{mV}$ 付近にコントロールしておくこ とが望ましい。

\section{2 パルプのカチオン要求量}

新聞原料の電荷に影響を与えている因子を調べるた めに, 各種のパルプに硫酸バンドを添加してゼー夕電 位を電気泳動法で測定した。ゼー夕電位が等電点に達 するまでに必要な硫酸バンド量はTMP が最も多く, SBKP が最も少なく,DIP がその中間であった(図 18)。 即ち, カチオン要求量は TMP $>$ DIP $>$ SBKP の順で あった。化学パルプにはリグニンとへミセルロースの 含有量が少ないが, 機械パルプにはへミセルロースが 残留している。また機械パルプは，磨砕の際に樹脂酸， 脂肪酸が溶出し, また微細繊維が多いので比表面積が 


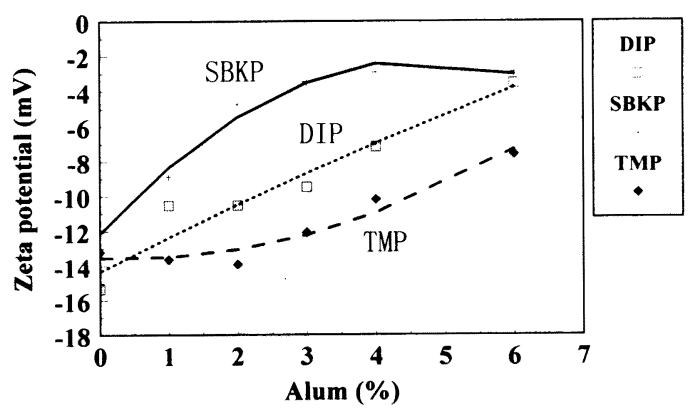

Fig.18 Effect of alum on zeta potential changes of TMP, SBKP and DIP ${ }^{5)}$

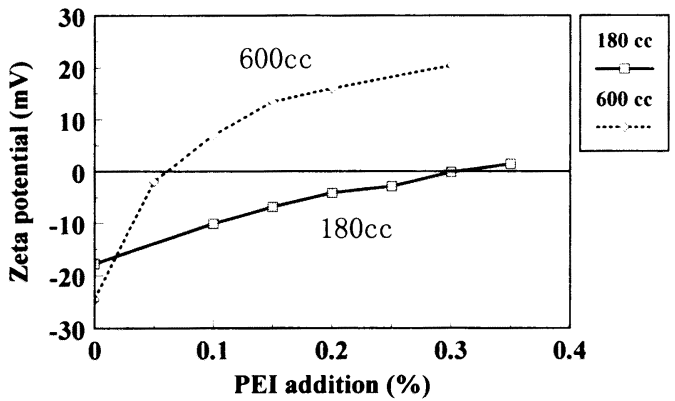

Fig.19 Effect of beating on zeta potential changes of $\mathrm{LBKP}^{5}$

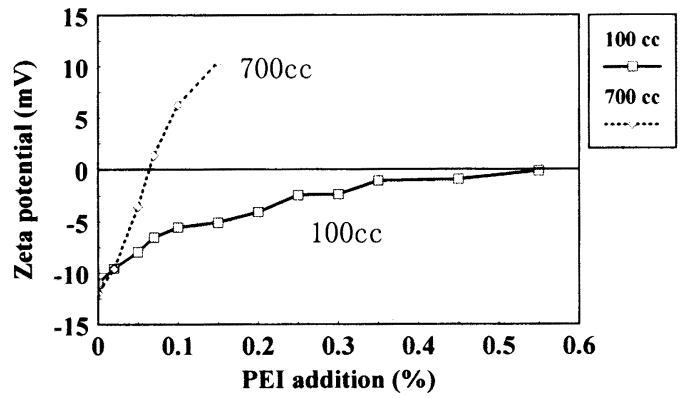

Fig.20 Effect of beating on zeta potential changes of $\mathrm{NBKP}^{5}$

多い。化学パルプも叨解すると, 纎維のフィブリル化, 切断が起こり, 比表面積が増大するので, ゼー夕電位 が等電点に達するまでに必要な力チオン性薬品量は増 加する(図 19, 20)。コロイド滴定でカチオン要求量 を測定した結果も同様であった(図 21)。TMPを䇫 い分けして, 長緎維と微細繊維とを分別し, それらを 再配合して微細繊維含有量が異なる試料を調成し，力 チオン性薬品を添加した時のゼー夕電位の変化を測定 した。微細繊維配合率が多くなるほど比表面積が増大 し, 力チオン要求量は増加した(図 22)。

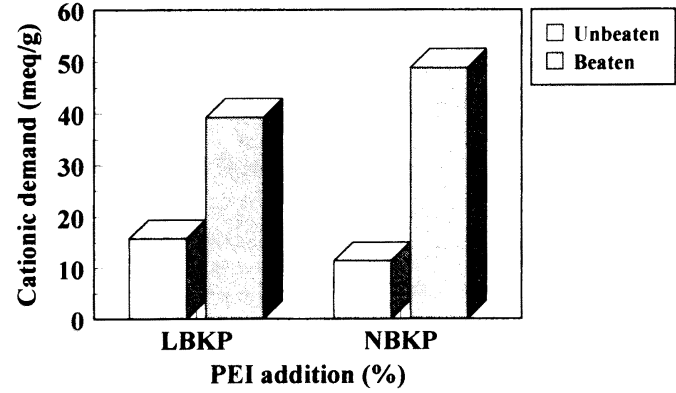

Fig.21 Effect of beating on cationic demand of LBKP and NBKP ${ }^{5}$

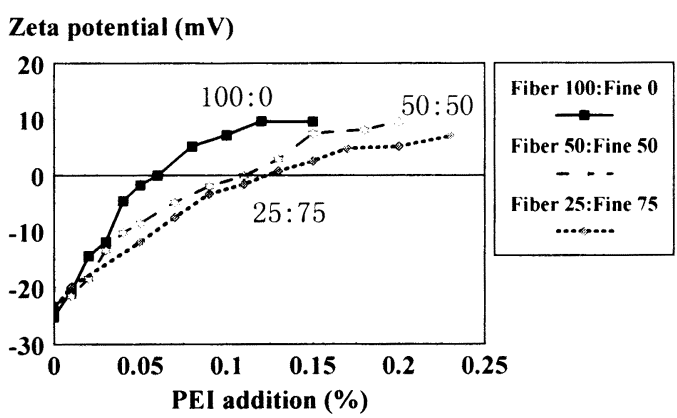

Fig.22 Effect of fiber length on zeta potential changes of $\mathrm{TMP}^{5)}$

\section{3 ゼー夕電位の凝集への影響}

抄紙機のウエットエンドに於いて歩留まり，濾水度， 地合のコントロールが最も重要である。実機での凝集 は, ポンプ, スクリーン, ワイヤーパートの脱水エレ メントなどの流体力学的力の影響を受けるので, 従来 の静的実験では実機のウエットエンドの挙動を予測す ることは難しい。そこで，ポンプで試料を循環させて 流体力学的力を加えながら, 順次薬品を添加して, ゼ 一夕電位, 凝集をオンライン測定し, ゼー夕電位が凝 集に及ぼす影響を考察した。

ベントナイトを使ったマイクロパーテイクル歩留り システムの実験結果を紹介する。上質モデルとして LBKP に沈降性軽質炭酸カルシウム（PCC）を $20 \%$ 配合し， $0.5 \%$ に稀釈して試料とした。ポンプで試料 をタンクとセンサーの間を循環させながら，カチオン 性澱粉が無添加（ケース 13）, 添加（ケース 14）の条 件で，カチオン性 PAM とベントナイトを順次試料 タンクに添加した。図 23 にゼー夕電位の変化を示した。 図 24 は凝集センサーの出力值で下方のピークが凝集 を示している。力チオン性澱粉無添加（ケース 13）

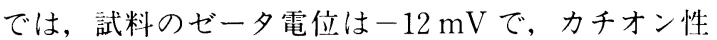
PAM とベントナイトを加えても弱い凝集しか起こら 


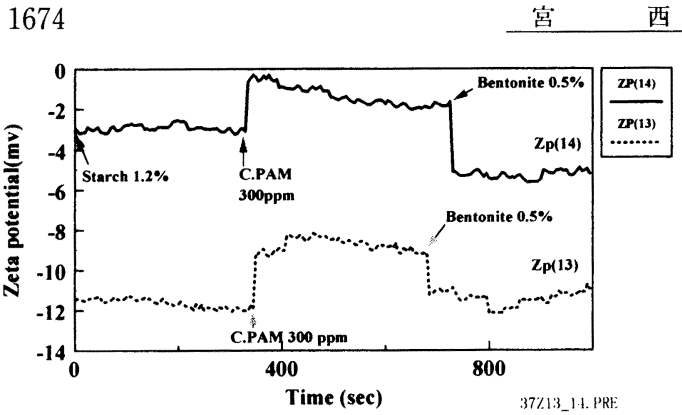

Fig.23 Zeta Potential of Woodfree 13 \& 14: (C. Starch) + C.PAM + Bentonite $^{6)}$

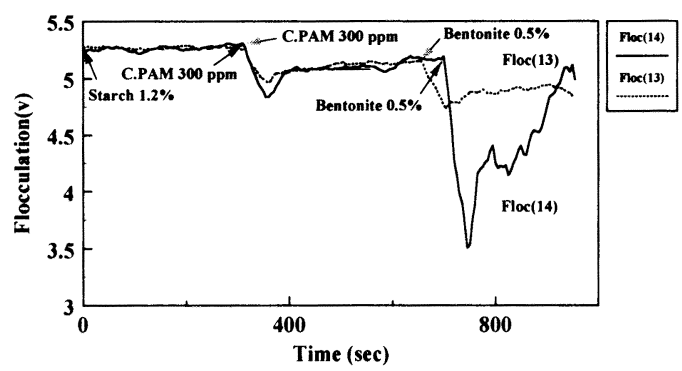

Fig.24 Flocculation of Woodfree 13 \& 14: (C. Starch) + C.PAM + Bentonite $^{6)}$

なかった。それに対してカチオン性澱粉を予为添加し

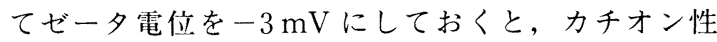
PAM を添加しても弱い凝集しか起こらなかったが, ベントナイトによって強い凝集が起こった（ケース 14)。

\section{4 ゼー夕電位コントロールによる凝集と濾水の 最適化}

次にゼー夕電位と凝集の他に濾水度も同時に計測し， ゼー夕電位が凝集と濾水度に及ぼす影響を調べた。図 25〜28 に凝集の強さと濾水度向上効果を縓めた。

上質条件では，凝集と濾水度は必ずしも一致しなか つた。例えばアニオン性 PAM 単独添加では凝集効 果がなく，滤水度が悪化した (ケース 1$)$ 。試料の電 荷がマイナスなのでアニオン性 PAM は分散剈とし て作用したことが推定されたが, poly-DADMACで 電荷を中和してからアニオン性 PAM を添加しても, 凝集は起こったものの, 濾水度は悪くなったことから， 電荷以外の要因もあると思われた（ケース 2$)$ 。

マイナス電荷を持つ繊維表面のフィブリルは同じく マイナスに帯電した繊維と反発し, 繊維表面から白水 中に突き出して滤過抵抗を増加させる作用がある。上 質原料には微細繊維は少なく, 強力チオン性の高分子 電解質は繊維表面に吸着し，プラスのパッチを形成す る。そしてそのパッチにアニオン性 PAM が投錨して,

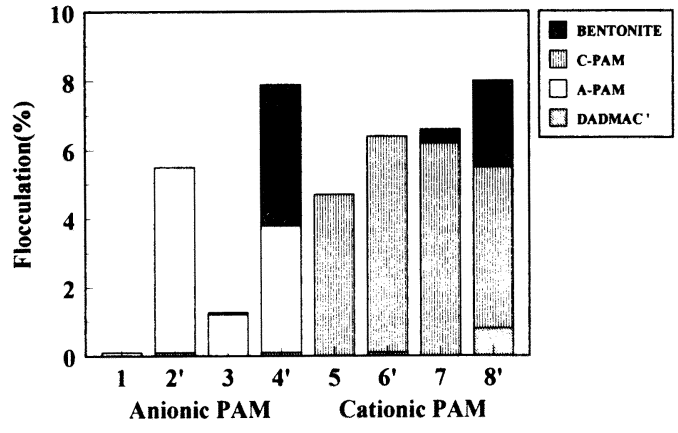

Fig.25 Flocculation of wood free grade ${ }^{7)}$ LBKP $100 \%$, PCC $20 \%, \mathrm{pH}=7.8$

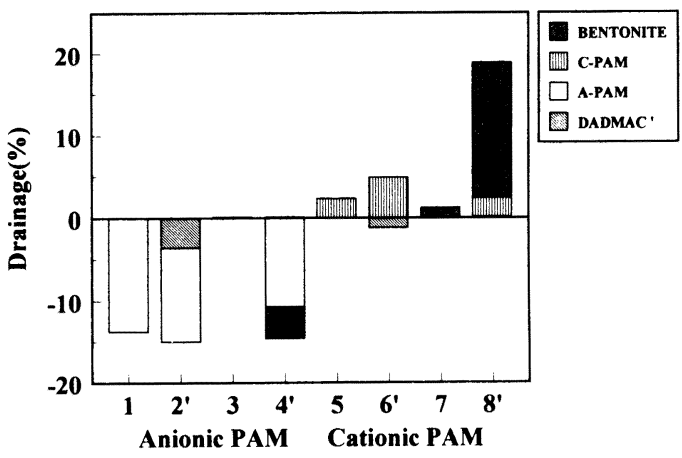

Fig.26 Drainage of wood free grade ${ }^{7)}$ LBKP $100 \%$, PCC $20 \%, \mathrm{pH}=7.8$

フロックを作る(図 30)。繊維との電荷の反発により アニオン性 PAM 分子の再配置は起こりにくく, 繊 維表面のフィブリルはPAMに影響されることなく， そのまま水中に突き出ている。このようにアニオン性 PAM は滤水度向上効果がないばかりか, 䋊維表面か ら離れている分子のテールが白水の粘度を上昇させて 濾過作用に悪影響を及ぼすと考えられる。PolyDADMAC，アニオン性 PAM，マイクロパーテイク ルを組み合わせても凝集は起きるが，滤水度は向上し なかった（ケース4)。それに対してカチオン性 PAM を添加すると凝集, 滤水度とも增加した（ケー 又 5，6)。力チオン性 PAM はマイナス電荷を持つ繊 維に直接架橋し，電荷の引力によって再配置しやすく 繊維表面上のフィビリルの突出を押さえる㗢きがある ものと思われる。

次にマイクロパーテイクルシステムについて考察す る。図 29 に上質原料のゼー夕電位, 凝集, 滤水度の 変化を示した。ゼー夕電位が- $15 \mathrm{mV}$ 付近では, シ ングルシステム (ケース 5$)$ でもマイクロパーテイク ルシステム (ケース 7) でも濾水度は向上しなかった。 


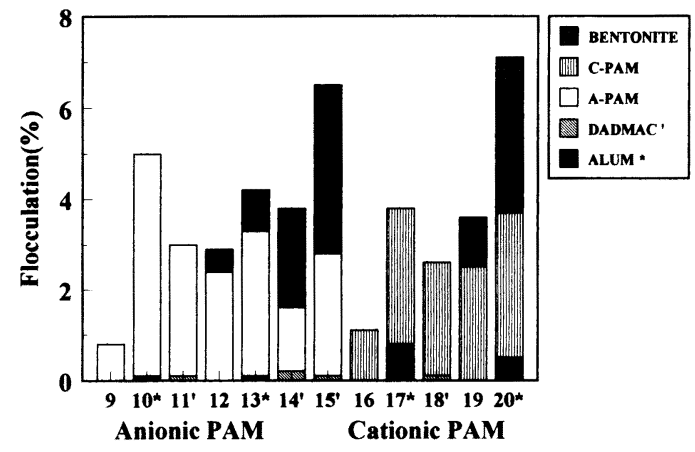

Fig. 27 Flocculation of wood containing grade ${ }^{7)}$ LBKP $60 \%$, GP $40 \%$, talc $15 \%$

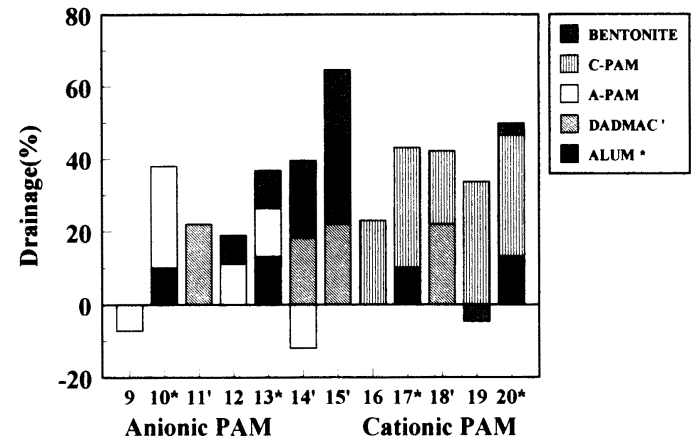

Fig.28 Drainage of wood containing grade ${ }^{7)}$ LBKP $60 \%$, GP $40 \%$, talc $15 \%$

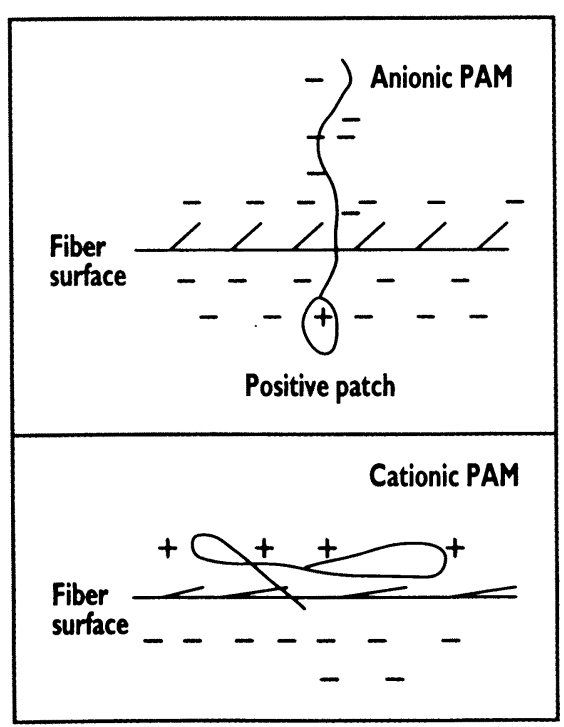

Fig.30 Changes of fibrils on the fiber surface, illustrating (top) anionic and (bottom) cationic polyacrylamide adsorption ${ }^{7}$

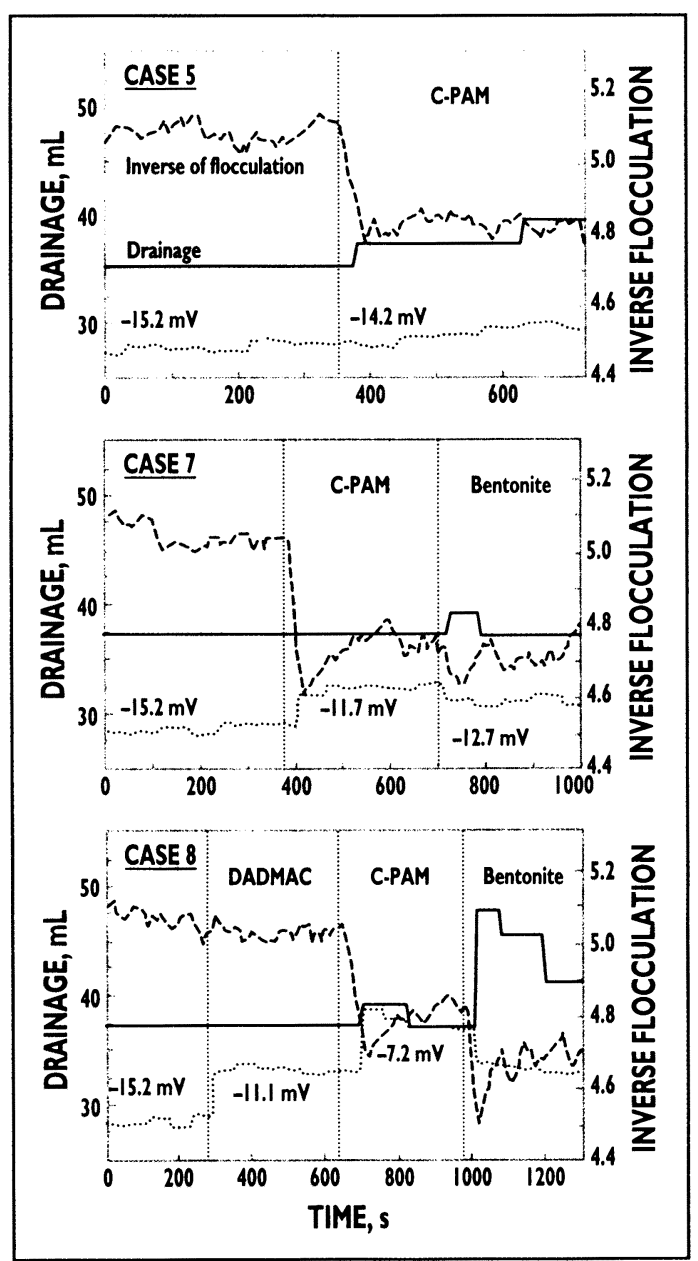

Fig.29 In the groundwood-free grade, cationic PAM was added for Cases 5,7 , and 8 . In Case 7 , bentonite was added after cationic PAM. In Case 8, DADMAC was added first, followed by cationic PAM and then bentonite. (100\% LBK$\mathrm{P}, 20 \%$ PCC added, $\mathrm{pH} 7.8)^{7)}$

電荷を $-11 \mathrm{mV}$ まで中和してから, カチオン性 PAM とベントナイトを添加すると凝集, 濾水度向上に大き な効果があった（ケース 8)。各薬品の添加における 濾水度向上効果を見てみると, 電荷中和, カチオン性 P AMそれ自体では効果がなかったが, ベントナイト で濾水度が大きく向上していることがわかる。

図 31 に中質原料の結果を示した。中質原料では上 質原料と異なり，電荷を中和する段階で既に濾水度向 上が見られた。中質原料は機械パルプの微細纎維を多 く含み, 微細纎維は比表面積が大きく, 繊維に比べて 


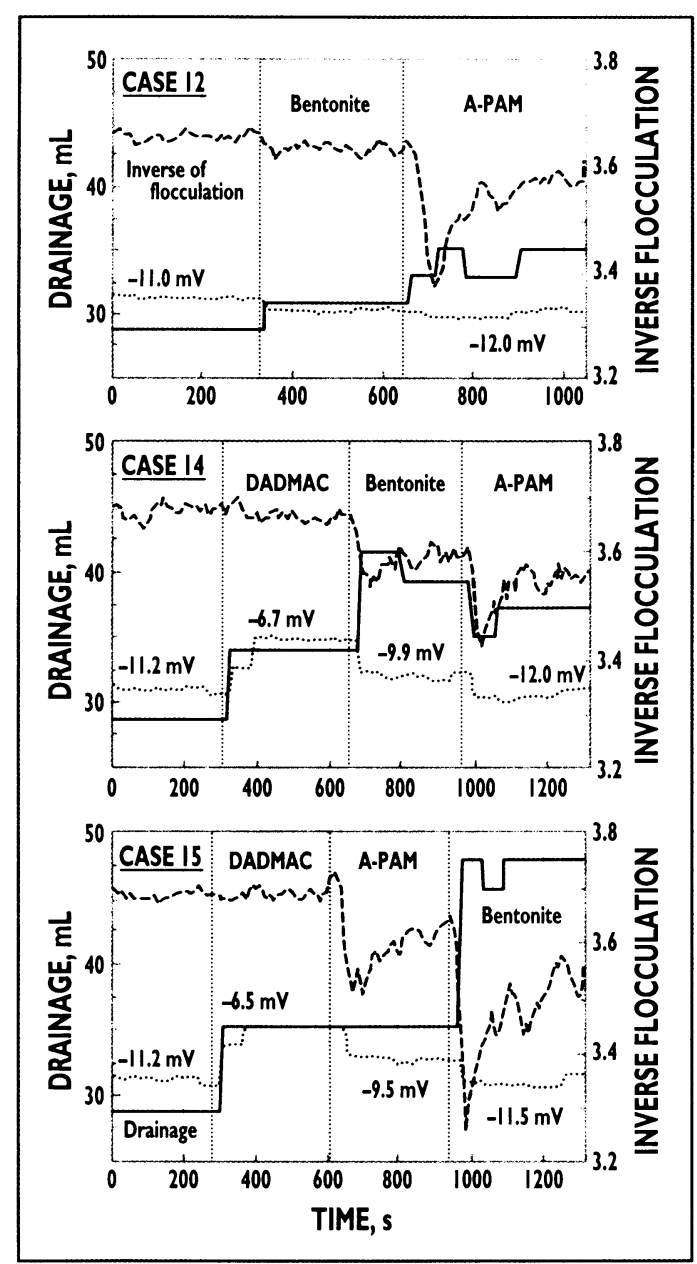

Fig.31 In the groundwood-containing grade, bentonite plus A-PAM made up Case 12. The sequence for Case 14 was DADMAC, bentonite, and A-PAM. For Case 15, the sequence was DADMAC, APAM, and bentonite. (60\% LBKP and $40 \%$ groundwood, $15 \%$ talc, ph 6.8$)^{7)}$

$2 \sim 3$ 倍の水を保持し膨潤して, 濾水度に強く影響を 子えている。電解質は比表面積の大きな微細繊維に選 択的に吸着し, 電荷が中和された微細繊維が繊維表面 に定着する。その結果, 繊維マット中の多孔構造の目 詰まりが減少し, 滤過抵抗が減って, 滤水度が増加す ると考えられる。中質原料のマイクローパーテイクル システムでは，カチオン性 PAMよりもアニオン性 PAMのほうが滤水度向上に効果があった。薬品添加 順序が大切で，電荷を中和しても，ベントナイトをア ニオン性 PAMより先に添加すると効果が小さく

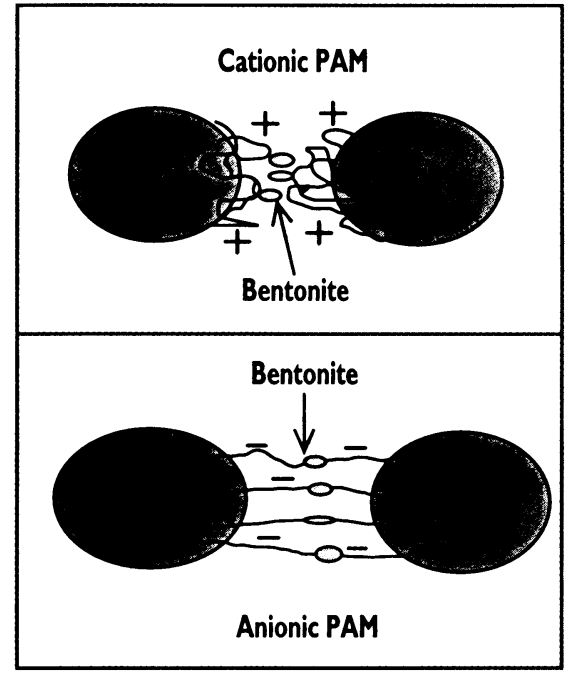

Fig.32 Proposed drainage models illustrating (top) the bridge model and (bottom) the patch-bridge model ${ }^{7)}$

(ケース 14)，アニオン性 PAM+ベントナイトの順 に添加した方が最も効果があった（ケース 15）。中質 原料のフロック架橋モデルでは, アニオン性 PAM を使った方が, フロックとフロックの間隔が長くなり， 微細繊維による目詰まりの影響が少なくなることが考 えられる(図 32)。

以上のことから中質原料と上質原料では, 最適薬品 の種類と添加順序は異なるが, 何れの条件でも, 步留 まりと濾水度を安定的に向上させるには, ゼ一夕電位 のコントロールが重要である。

5.おわりに

製紙会社の研究所におけるウエットエンド化学の役 割は, 大学の基礎研究と工場の生産とを橋渡しする生 産技術の開発である。近年，センサー，コンピュータ ーシミュレーション, 熱分解ガスクロマトグラフィー などの分析機器の進歩により, 抄紙機のウエットエン ドの変化が紙品質と操業に与える影響を定量的に把握 でき，理論を実機に適用できるようになってきた。そ の経済的効果は非常に大きく, 今後の展開が期待され ている。

\section{引用文献}

1) Miyanishi, T., Iida, K., and Iwatsu, T. : "Dynamic Simulation for Efficient Paper Machine Grade Change”, TAPPI J. 71(1) : 49(1988).

2) Miyanishi, T., Iida, K., and Iwatsu, T. : "Drainage Analysis of Curved Forming Shoes 
on Twin-wire Formers", TAPPI J. 72(7): 81 (1988).

3) Miyanishi, T., Imamura, K. and Hata, K. : "A New Wet-end Control System with On-line Sensors", TAPPI J. 73(7): 128(1990).

4) Miyanishi, T. and Miyagi, M. : "Effects of Fines on Offset Newsprint Linting", TAPPI J. 75(5): 75(1992) .

5) Miyanishi, T. : "On-line Zeta Potential Analysis of a Fine Paper Machine and a Newsprint
Paper Machine", TAPPI J. 78(3): 85(1995).

6) Miyanishi, T. : "Effects of Zeta Potential on Dynamic Flocculation in Microparticle Systems", TAPPI J. 78(11) : 136(1995).

7) Miyanishi, T., and Motegi, S. : "Optimization of Flocculation and Drainage for Microparticle Systems by Zeta Potential Control”, TAPPI J. 80(1): 262(1997).

8）田中浩雄 “概論”, 第 4 回製紙技術セミナー, 平 成 10.9 .17 , 北とぴあ 